\title{
Disruption of a Gene Essential for Sulfoquinovosyldiacylglycerol Biosynthesis in Sinorhizobium meliloti Has No Detectable Effect on Root Nodule Symbiosis
}

\author{
Barbara Weissenmayer, ${ }^{1}$ Otto Geiger, ${ }^{2}$ and Christoph Benning ${ }^{3}$ \\ ${ }^{1}$ Institute of Biotechnology, Technical University, Seestrasse 13, 13353 Berlin, Germany; \\ ${ }^{2}$ Centro de Investigación sobre Fijación de Nitrógeno, Universidad Nacional Autónoma de México, \\ Apdo. Postal 565-A, Cuernavaca, Morelos, CP62210, México; ${ }^{3}$ Department of Biochemistry, \\ Michigan State University, East Lansing 48824-1319, U.S.A. \\ Accepted 24 February 2000.
}

The sulfolipid sulfoquinovosyldiacylglycerol is commonly found in the thylakoid membranes of photosynthetic bacteria and plants. While there is a good correlation between the occurrence of sulfolipid and photosynthesis, a number of exceptions are known. Most recently, sulfoquinovosyldiacylglycerol was discovered in the non-photosynthetic, root nodule-forming bacterium Sinorhizobium meliloti. This discovery raised the questions of the phylogenetic origin of genes essential for the biosynthesis of this lipid in $S$. meliloti and of a function of sulfolipid in root nodule symbiosis. To begin to answer these questions, we isolated and inactivated the $s q d B$ gene of $S$. meliloti. This gene and two other genes located directly $3^{\prime}$ of $s q d B$ are highly similar to the $s q d B, s q d C$, and $s q d D$ genes known to be essential for sulfolipid biosynthesis in the photosynthetic, purple bacterium Rhodobacter sphaeroides. This observation confirms the close phylogenetic kinship between these two species. Furthermore, the reduced similarity of $s q d B$ to the plant ortholog SQD1 of Arabidopsis thaliana does not support a previous sqd gene transfer from the plant as a consequence of close symbiosis. A sulfolipid-deficient mutant of $S$. meliloti disrupted in $s q d B$ is capable of inducing functional nodules and does not show an obvious disadvantage under different laboratory culture conditions. Thus far, no specific function can be assigned to bacterial sulfolipid, in either nodule-associated or free-living cells. S. meliloti contains a rich set of polar membrane lipids some of which, including sulfolipid, may become critical only under growth conditions that still need to be discovered.

Additional keyword: Rhizobium.

Corresponding author: Christoph Benning; Mailing address: Department of Biochemistry, Michigan State University, East Lansing 48824-1319, U.S.A.; Telephone: 1-(517)-355-1609; Fax: 1-(517)-353-9334; E-mail: benning@ @ilot.msu.edu

Nucleotide and/or amino acid sequence data have been deposited in the GenBank data base as accession no. AF194444.
The sulfolipid sulfoquinovosyldiacylglycerol widely occurs in photosynthetic organisms ranging from bacteria to seed plants (Benning 1998; Haines 1973; Harwood 1980; Heinz 1993), where it is associated with photosynthetic membranes. However, the analysis of sulfolipid-deficient null mutants of the purple bacterium Rhodobacter sphaeroides and the cyanobacterium Synechococcus strain PCC7942 suggested that sulfolipid is not as generally essential for photosynthesis as one might be tempted to think based on its prevalence in photosynthetic organisms. However, it is required for growth under phosphate-limiting growth conditions in $R$. sphaeroides and Synechococcus strain PCC7942 (Benning et al. 1993; Güler et al. 1996). There are now several confirmed reports of the presence of sulfoquinovosyldiacylglycerol in nonphotosynthetic bacteria: a gram-positive, extremely thermoacidophilic bacterium from the genus Alicyclobacillus formerly called Bacillus acidocaldarius (Langworthy et al. 1976), several Caulobacter and Brevundimonas spp. (Abraham et al. 1997), and Sinorhizobium meliloti (formerly called Rhizobium meliloti; Cedergreen and Hollingsworth 1994). The interaction of $S$. meliloti or similar bacteria, collectively called rhizobia, with the roots of leguminous host plants leads to the formation of nodules in which atmospheric nitrogen is fixed. Lipo-chitin oligosaccharides produced by the bacteria act as nodulation signals (Dénarié et al. 1996; Schultze et al. 1994). Furthermore, certain cyclic glucans (Breedveld and Miller 1994), exopolysaccharides (Leigh and Walker 1994), lipopolysaccharides (Noel 1992), and K-like capsular polysaccharides (Reuhs et al. 1995) are required for the infection process and for the colonization of the root nodule. The importance of these compounds for successful symbiosis has been determined by the analysis of the respective biochemical mutants. In many cases, such mutants lead to the formation of nodules incompetent for nitrogen fixation, but free-living cells are not impaired in their growth rates. Because bacteroids are in close contact with plant membranes during the infection process in the nodules, it seems conceivable that certain membrane lipids in the plant or bacteroids may be important for successful nodule formation. S. meliloti shows a rich complement of membrane lipids (Goldfine 1987) and changes its membrane lipid composition 
in response to environmental stresses such as phosphate deprivation (Geiger et al. 1999). The discovery of sulfolipid in $S$. meliloti raised two questions (Cedergreen and Hollingsworth 1994): (i) Are S. meliloti sqd genes evolutionary derived from close bacterial relatives or from the host plant during the intimate symbiotic relationship? and (ii) What, if any, role does sulfolipid play in nodule formation and function? With the availability of four sqd genes from $R$. sphaeroides (Benning and Somerville 1992a, 1992b; Rossak et al. 1995) as well as cyanobacterial and plant $s q d B$ orthologs (Essigmann et al. 1998; Güler et al. 1996), these questions can be experimentally addressed. The most highly conserved sulfolipid gene in bacteria, $s q d B$, and its ortholog in plants, $S Q D 1$, encode for an enzyme involved in the biosynthesis of UDP-sulfoquinovose from UDP-glucose and an unknown sulfur donor (Essigmann et al. 1999; Mulichak et al. 1999). While the function of the bacterial $s q d A$ gene in sulfolipid biosynthesis remains unclear, $s q d C$ and $s q d D$ are thought to catalyze the transfer of sulfoquinovose from UDP-sulfoquinovose to diacylglycerol (Rossak et al. 1995, 1997). Here, we describe the isolation and characterization of $s q d$ genes from $S$. meliloti, as well as the inactivation of $s q d B$ and subsequent analysis of the resulting sulfolipid-deficient mutant with regard to bacterial growth, nodule formation, and nodule function.

\section{RESULTS}

\section{Isolation of a putative $s q d B$ ortholog} and surrounding DNA from $S$. meliloti.

Relying on the strong conservation of $s q d B$ DNA and amino acid sequences from different bacteria, degenerate primers against the $s q d B$ gene from $R$. sphaeroides were designed. These primers were used to polymerase chain reaction (PCR) amplify and clone the corresponding fragment from $S$. meliloti genomic DNA, giving rise to plasmid pBW1 as shown in Figure 1. The insert of pBW1 served as homologous probe for screening of a genomic phage library of $S$. meliloti by DNA/ DNA hybridization. Several overlapping clones hybridizing to the probe were isolated. The clone containing the longest insert, pBW9, was sequenced. Sequence analysis and preliminary comparison to the sqd genes from $R$. sphaeroides revealed two complete and one partial open reading frame (Fig. 1). The predicted amino acid sequence of the first open reading frame showed high sequence similarity to the $s q d B$, the

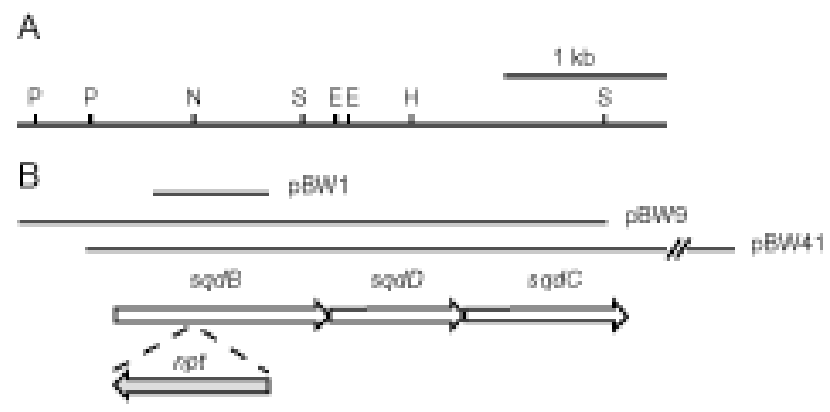

Fig. 1. Restriction map of Sinorhizobium meliloti genomic DNA containing (A) sqd genes and (B) clone and gene location. Insertion point and orientation of 0.9-kb DNA fragment (gray arrow) containing neomycin phosphotransferase (npt) cassette in mutant SL11 are indicated. Restriction sites: B, BglII; E, EcoRI; H, HindIII; N, NcoI; P, PstI; S, SalI). second to the $s q d D$, and the third to the $s q d C$ gene products of $R$. sphaeroides. Because only the $5^{\prime}$ end of $s q d C$ was present on $\mathrm{pBW} 9$, and because no other $3^{\prime}$ extending clones were available, a cosmid library containing genomic DNA fragments of $S$. meliloti was probed with the pBW1 insert. The cosmid cosSL1 completely containing all three genes was isolated. A 10-kb Pst I fragment derived from this cosmid was subcloned (pBW41) and used as the template to complete sequencing of $s q d C$. The assembled sequence of 3,989 bp was submitted to GenBank (accession no. AF194444). Detailed analysis revealed an open reading frame (base pairs 612 to 1829) encoding a putative protein of 406 amino acids with high amino acid sequence similarity to the $s q d B$ gene product of $R$. sphaeroides (79\% identity). The second open reading frame (base pairs 1829 to 2701) encoded a putative protein of 291 amino acids with a $62 \%$ identity to the $s q d D$ gene product of $R$. sphaeroides, and the third open reading frame (base pairs 2701 to 3624 ) encoded a putative protein of 308 amino acids with $47 \%$ identity to the $s q d C$ gene product of $R$. sphaeroides.

\section{The putative sqd genes of $S$. meliloti are most likely of bacterial and not plant origin.}

The analysis of the organization of the putative $S$. meliloti $s q d$ genes and their similarity to the presumed orthologs from $R$. sphaeroides suggests that they have a common bacterial ancestor. Because the bacterial $s q d B$ genes and the plant ortholog SQD1 from A. thaliana are known to be highly conserved (Benning 1998), they provide an ideal basis for an analysis of relatedness and evolution of sulfolipid head group biosynthesis in different organisms. Figure 2 shows a tree predicting the evolutionary relatedness of the $s q d B / S Q D 1$ genes based on amino acid sequence identity. It is apparent that the two $s q d B$ orthologs from $R$. sphaeroides and $S$. meliloti are closest to each other and that $S Q D 1$ is most distant from $s q d B$ of $S$. meliloti. This result provides a satisfying answer to the question of the origin of sqd genes in S. meliloti raised by Cedergreen and Hollingsworth (1994). It seems unlikely that $S$. meliloti acquired sqd genes from the host plant during the symbiotic interaction. Rather, this analysis confirms the close relationship between $R$. sphaeroides and $S$. meliloti, which are both classified in the $\alpha$ division of gram-negative bacteria (Woese 1987).

\section{The $s q d B$ gene of $S$. meliloti is essential for sulfolipid biosynthesis.}

To obtain functional proof for the $s q d B$ ortholog of $S$. meliloti, the respective gene was inactivated by targeted gene

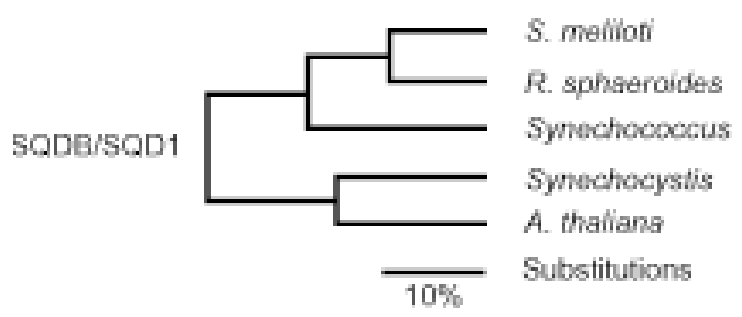

Fig. 2. Phylogenetic tree based on similarity of bacterial SQDB and plant SQD1 proteins. Length of the branches is drawn to scale (10 substitutions per 100 residues are as indicated). 
disruption. A neomycin phosphotransferase cassette was inserted into the $s q d B$ open reading frame, leading to the isolation of mutant strain SLD11. Figure 1B shows the arrangement of genes in the mutant. Comparison of genomic DNA from the wild type and SLD11 by DNA/DNA hybridization confirmed the complete loss of wild-type genome copies in SLD11 and their replacement with mutant genome copies (Fig. 3). Most informative was a restriction digest with EcoRI probed with the insert of $\mathrm{pBW} 1$, giving rise to a diagnostic $3.2-\mathrm{kb}$ band in the wild type and a $4.2-\mathrm{kb}$ band in SLD11. To test the primary consequences of the $s q d B$ gene disruption in

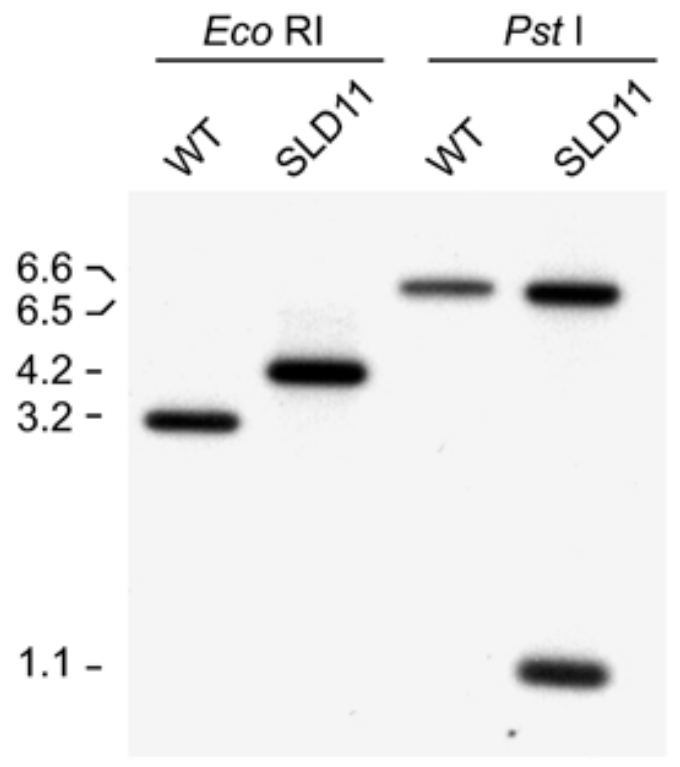

Fig. 3. Southern blot of genomic DNA from wild type (WT) and SLD11 digested with enzymes as indicated and probed with the insert of pBW1. Approximate fragment sizes $(\mathrm{kb})$ are indicated.

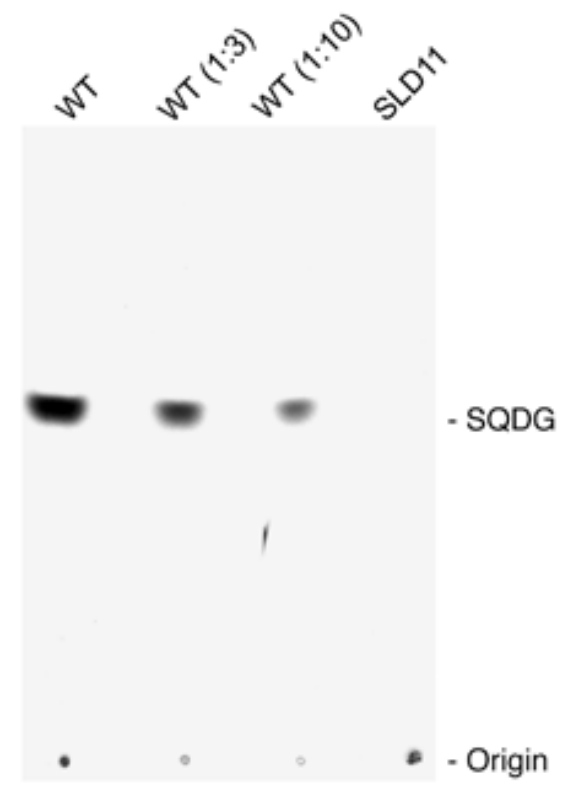

Fig. 4. Thin-layer chromatography of $\left[{ }^{35} S\right]$ sulfate labeled extracts from wild type (WT) and SDL11. Dilutions of extracts (1:3 or 1:10) are indicated. Lipids were visualized by exposure to X-ray film.
S. meliloti, lipids of the wild type and SLD11 were compared by thin-layer chromatography (TLC) following labeling of the cells with $\left[{ }^{35} \mathrm{~S}\right]$ sulfate (Fig. 4). A single band co-chromatographing with bacterial and plant sulfolipid was detected in the wild-type samples that was completely absent in the extracts of SLD11, suggesting that this strain is a sulfolipiddeficient null mutant. When cosmid cosSL1 carrying $s q d B$ and other adjacent genes was reintroduced into SLD11, sulfolipid biosynthesis was restored, consistent with genetic complementation (data not shown). Thus, $s q d B$ of $S$. meliloti is a functional ortholog of the bacterial and plant $s q d B / S Q D 1$ genes that is essential for sulfolipid biosynthesis in $S$. meliloti.

\section{Sulfolipid deficiency has only subtle effects on growth of S. meliloti.}

To begin to understand the role of sulfolipid in membranes of non-photosynthetic bacteria, in this case $S$. meliloti, growth of mutant and wild-type cells was compared in minimal medium containing sufficient or growth-limiting amounts of phosphate. In photosynthetic bacteria such as the purple bacterium $R$. sphaeroides or the cyanobacterium Synechococcus strain PCC7942, phosphate limitation specifically affects growth of sulfolipid-deficient null mutants and causes changes in membrane lipid composition (Benning et al. 1993; Güler 1996). Based on this observation, it has been proposed that sulfolipid substitutes for anionic phospholipids under phosphate-limiting growth conditions, thereby permitting maintenance of a functional photosynthetic membrane (Benning 1998). Comparing growth of the wild type and SLD11 in media with sufficient and 65-fold lower initial amounts of phosphate revealed a slight delay in growth of SLD11 under both conditions (Fig. 5). Growth rates for both strains were reduced in low-phosphate medium, but under the chosen conditions

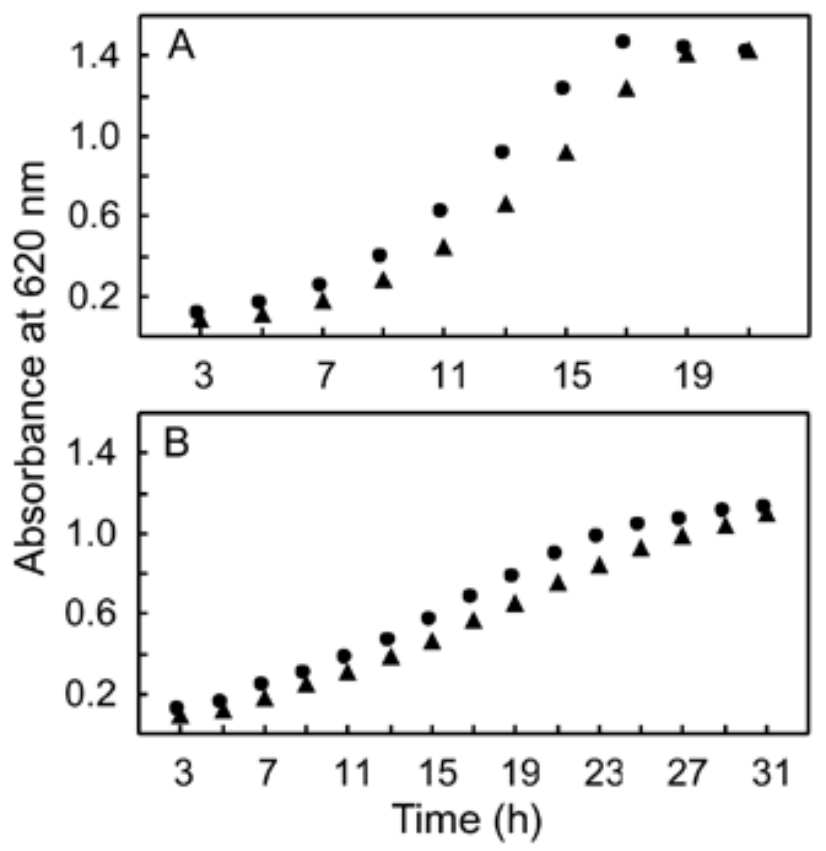

Fig. 5. Growth of wild type (WT) $(\bullet)$ and SDL11 (A) in (A) phosphate sufficient and (B) phosphate depleted minimal medium. Three independent cultures each were analyzed and averaged. Standard error bars are smaller than symbol size. 
there was no specific effect on growth of the sulfolipiddeficient null mutant, contrary to what was observed for photosynthetic bacteria (Benning et al. 1993; Güler et al. 1996). Cultures of both strains reached the same final optical density, but this could have been due to the accumulation of secreted material (e.g., polysaccharides) during later stages of the culture, and not due to actual cell divisions and growth. Despite the lack of dramatic reduction in growth of the mutant even under phosphate-limiting growth conditions, the lipid composition qualitatively changed, as had been observed for photosynthetic bacteria grown in low-phosphate medium (Table 1). However, the increase in the relative pool size of phosphatidylglycerol in the mutant compared with the wild type, a decrease in the pool size for this lipid in the wild type under phosphate limitation but not in the mutant, and an increase in the pool size of sulfolipid under phosphate limitation in the wild type, were more subtle in $S$. meliloti than observed in $R$. sphaeroides or Synechococcus strain PCC7942. Either the employed conditions did not lead to the extent of phosphate starvation needed to see differences in growth and lipid composition of $S$. meliloti wild type and mutant, or sulfolipid is not as critical in non-photosynthetic bacteria under phosphatelimiting growth conditions as it is in photosynthetic bacteria.

\section{The sqdB gene of $S$. meliloti is not essential for nodule formation or function.}

The discovery of sulfoquinovosyldiacylglycerol in $S$. meliloti tempted speculation that this lipid, typically found only in photosynthetic organisms, may play a role in the symbiotic association of $S$. meliloti and its host alfalfa (Cedergreen and Hollingsworth 1994). To test whether SLD11 can form functional nodules, aseptically grown alfalfa seedlings were inoculated with the wild type or the sulfolipid-deficient strain SLD11, or treated with water as a control, and further incubated on minimal medium lacking a nitrogen source. Plants inoculated with either wild type or SDL11 formed nodules and flourished, while the control plants lagged behind in growth and showed with time increasing signs of nitrogen deprivation. Closer inspections of the plant roots revealed nodules on plants inoculated with bacteria and no nodules on water-treated plants. Cross sections of nodules from plants

Table 1. Membrane lipid composition of Sinorhizobium meliloti wild type and SLD11 following incubation on high phosphate $(1.3 \mathrm{mM})$ or low phosphate $(0.02 \mathrm{mM})$ minimal medium

\begin{tabular}{|c|c|c|c|c|}
\hline \multirow[b]{3}{*}{ Lipid $^{\mathrm{a}}$} & \multicolumn{4}{|c|}{ Composition $\left(\% \text { of total }{ }^{14} \mathrm{C}\right)^{b}$} \\
\hline & \multicolumn{2}{|c|}{ High phosphate } & \multicolumn{2}{|c|}{ Low phosphate } \\
\hline & Wild type & SLD11 & Wild type & SLD11 \\
\hline G & $11.7 \pm 0.3$ & $12.8 \pm$ & $4.2-2$ & $10.4=$ \\
\hline $\mathrm{CL}$ & & & & \\
\hline PE/MMPE/DMPE & $22.8=$ & $20.6 \pm$ & .3 & $5.0 \pm 1.8$ \\
\hline $\mathrm{PC}$ & 46.5 & $49.7 \pm$ & 6.2 & $10.1 \pm 1.1$ \\
\hline SQDG & & & & $\mathrm{ND}^{\mathrm{c}}$ \\
\hline $\mathrm{OL}$ & 10.1 & 10.0 & & \\
\hline DGTS & $2.5 \pm 0.7$ & $2.7 \pm 0.3$ & $67.1 \pm 3.0$ & $59.5 \pm 3.5$ \\
\hline \multicolumn{5}{|c|}{$\begin{array}{l}\text { a CL, cardiolipin; DGTS, diacylglycerol- } N, N, N \text {,-trimethylhomoserine; } \\
\text { DMPE, } N, N \text {-dimethyl-phosphatidylethanolamine; MMPE, } N \text {-mono- } \\
\text { methyl-phosphatidylethanolamine; OL, ornithine lipid; PC, phosphati- } \\
\text { dylcholine; PE, phosphatidylethanolamine; SQDG, sulfoquinovosyldi- } \\
\text { acylgycerol. } \\
\text { b Mean } \pm \text { standard deviation; } n=3 \text {. }\end{array}$} \\
\hline
\end{tabular}

inoculated with either bacterium were reddish pink. Furthermore, there was no difference in the number of nodules developing over time on the roots of plants treated with wild-type or mutant bacteria (Table 2). Lipid analysis of bacteria reisolated from the nodules to confirm the bacterial phenotypes showed the same membrane lipid composition as found in cells used for inoculation. These observations suggest that there are no adverse effects on the development and function of nodules derived from $S$. meliloti lacking the sulfolipid sulfoquinovosyldiacylglycerol.

\section{DISCUSSION}

Since the discovery and structural elucidation of the "plant sulfolipid" sulfoquinovosyldiacylglycerol by Benson and coworkers 40 years ago (Benson 1963; Benson et al. 1959), researchers have speculated about a specific role for this lipid in photosynthetic organisms. However, based on mutant analysis it now seems clear that sulfolipid is not generally essential for photosynthesis, but is of conditional importance under phosphate-limiting growth conditions, at least in purple bacteria with non-oxygenic photosynthesis and in cyanobacteria with oxygenic, plantlike photosynthesis (Benning et al. 1993; Güler et al. 1996). The nodule-forming bacterium $S$. meliloti is closely related to the purple bacterium $R$. sphaeroides (Woese 1987), but cannot carry out photosynthesis. The analysis of the sulfolipid-deficient mutant of $S$. meliloti revealed qualitative changes in lipid composition in response to phosphate deprivation (Table 1) similar to those observed for $R$. sphaeroides or the cyanobacterium Synechococcus strain PCC7942, but, unlike those photosynthetic bacteria, growth was not specifically reduced under phosphate-limiting conditions (Fig. 5B). This observation suggests that sulfolipid may have a distinct function in photosynthetic bacteria different from that in non-photosynthetic bacteria, but only under certain conditions, when anionic lipids such as phosphatidylglycerol become scarce and need to be replaced by a nonphosphorous lipid. If the sqd genes are not simply "ancestral baggage" passed on from the progenitor of $R$. sphaeroides and $S$. meliloti, what is the function of sulfolipid in $S$. meliloti? Because sulfolipid does not seem to be critical for the growth of free-living cells of $S$. meliloti, at least under the conditions tested, the question arises whether this lipid may be important for bacteroids. However, inoculation of roots with $S$. meliloti inactivated in $s q d B$ leads to the formation of functional nod-

Table 2. Nodule formation on roots of alfalfa seedlings

\begin{tabular}{lccccc}
\hline & \multicolumn{4}{c}{ Nodules per plant ${ }^{\mathbf{b}}$} \\
\cline { 2 - 3 } Days $^{\mathbf{a}}$ & \multicolumn{2}{c}{ Experiment 1 } & & \multicolumn{2}{c}{ Experiment 2 } \\
\cline { 2 - 3 } \cline { 5 - 6 } & WT & SLD11 & & WT & SLD11 \\
\hline 5 & 0 & 0 & & 0 & 0 \\
10 & 0.7 & 0.3 & & 1.2 & 0.3 \\
15 & 1.0 & 1.0 & & 1.5 & 1.3 \\
20 & 1.3 & 1.3 & & 3.0 & 2.3 \\
25 & 1.5 & 2.0 & & 3.0 & 2.7 \\
30 & 1.8 & 2.0 & & 3.2 & 3.5 \\
35 & 2.3 & 2.0 & & 3.2 & 3.5 \\
40 & 2.3 & 2.0 & 3.2 & 3.5 \\
45 & 2.5 & 2.0 & 3.2 & 3.5 \\
\hline
\end{tabular}

${ }^{a}$ Days after inocculation with bacteria.

${ }^{\mathrm{b}}$ Mean value derived from six plants. 
ules indistinguishable from those induced by wild-type cells. Unless there is a second pathway for sulfolipid biosynthesis independent of the here-described $s q d$ genes and specific for bacteroids, sulfolipid clearly has no specific function in nodule formation and nitrogen fixation. Thus, one can only speculate that the capability to synthesize sulfolipid increases the metabolic plasticity of $S$. meliloti, a predisposition for swift adaptations to changes in the environment.

The discovery of sulfoquinovosyldiacylglycerol in $S$. meliloti by Cedergreen and Hollingsworth (1994) also poses the interesting question of the origin of $s q d$ genes in this bacterium. It seemed plausible that the $s q d$ genes of $S$. meliloti were acquired by lateral gene transfer from plants as a result of symbiosis. However, comparison of $s q d B$ orthologs from plants and bacteria clearly excludes this possibility, because $S$. meliloti $s q d B$ is most distant from the plant ortholog (Fig. 2). On the other hand, the $s q d B$ gene products of $R$. sphaeroides and $S$. meliloti are very similar in sequence and confirm the close phylogenetic kinship of the two bacteria (Woese 1987). It should be pointed out that there are actually photosynthetic, nodule-forming rhizobia (So et al. 1994). Thus, it seems plausible that $R$. sphaeroides and $S$. meliloti evolved from a common photosynthetic progenitor. While $S$. meliloti lost its photosynthetic capability, it maintained functional sqd genes. In conclusion, rhizobia are interesting not only because of their symbiotic interaction with plants but also because they are placed in the evolutionary tree at a branch point of photosynthetic and non-photosynthetic bacteria. The sulfolipid biosynthetic pathway is an interesting example of the evolution of a pathway primarily, but not exclusively, associated with photosynthetic organisms and a more extensive comparison of sqd gene structures throughout the phylogenetic tree may provide novel insights into the evolution of photosynthetic organisms.

\section{MATERIALS AND METHODS}

Bacterial strains, plasmids, media, and growth conditions. Strains and plasmids used in this study are listed in Table 3. Sinorhizobium (Rhizobium) meliloti strains were grown at $29^{\circ} \mathrm{C}$ in tryptone/yeast extract (TY) medium (Beringer 1974) or in minimal medium (Sherwood 1970) with succinate $(8.3$ $\mathrm{mM}$ ) replacing mannitol as carbon source (de Rudder et al. 1997). Escherichia coli strains were grown at $37^{\circ} \mathrm{C}$ in LuriaBertani (LB) medium. Antibiotics were added when required to obtain the following final concentrations (in mg of medium per liter): streptomycin, 500; gentamicin, 60; neomycin, 50; piperacillin, 40; and tetracycline, 2 for S. meliloti; and carbenicillin, 100; gentamicin, 10; kanamycin, 50; and tetracycline, 20, for E. coli.

\section{Construction of an $s q d B$ probe and screening of genomic libraries.}

An approximately 700-bp genomic DNA fragment of the sinorhizobial $s q d B$ ortholog was PCR amplified with degenerated primers TTGGATCCCSCCCTATTCRATGAAG and TTGGTACCTGCGKGGRTTGGGCAGG, annealing temperature $58^{\circ} \mathrm{C}$. These primers were designed based on highly conserved regions of the $s q d B$ genes from $R$. sphaeroides 2.4.1 (Benning and Somerville 1992b) and Synechococcus strain PCC7942 (Güler et al. 1996). The DNA fragment was blunt end-ligated into an EcoRV-digested pBSIISK ${ }^{+}$vector to obtain $\mathrm{pBW} 1$. The insert of plasmid pBW1 was subsequently used to screen for larger genomic clones containing the fulllength $S$. meliloti $s q d B$ and adjacent genes. Two different genomic libraries of $S$. meliloti 1021 were used: a cosmid library and a newly prepared lambda-ZAP-Express (Stratagene, La Jolla, CA) library. For this purpose, genomic DNA was

Table 3. Bacterial strains and plasmids used in this study

\begin{tabular}{|c|c|c|}
\hline Strain or plasmid & Relevant characteristics or genotype & Reference or source \\
\hline \multicolumn{3}{|c|}{ Sinorhizobium (Rhizobium) meliloti } \\
\hline Sm1021 & $\mathrm{Str}^{\mathrm{r}}$ of SU47 & Meade et al. 1982 \\
\hline SLD11 & Sm1021 with $n p t\left(\operatorname{Kan}^{\mathrm{r}}\right)$ in $s q d B$ & This study \\
\hline \multicolumn{3}{|l|}{ Escherichia coli } \\
\hline $\mathrm{DH} 5 \alpha \mathrm{F}^{\prime}$ & $\begin{array}{l}\mathrm{F}^{\prime} \text { endA1 hsdR17 }\left(\mathrm{r}_{\mathrm{K}}{ }^{-} \mathrm{m}_{\mathrm{K}}{ }^{+}\right) \text {supE44 thi-1 recA1 gyrA96 relA1 } \Delta \text { (lacIZYA- } \\
\text { argF)U169 deoR }(\phi \mathrm{F} 80 \text { dlac } \Delta(\text { lacZ)M15) }\end{array}$ & Woodcock et al 1989 \\
\hline XL-1 Blue & $\begin{array}{l}\text { endA1 hsdR17 }\left(\mathrm{r}_{\mathrm{K}}{ }^{-} \mathrm{m}_{\mathrm{K}}{ }^{+}\right) \text {supE44 thi-1 recA1 gyrA96 relA1 } \Delta l a c\left[\mathrm{~F}^{\prime} \text { proAB }\right. \\
\left.\quad \text { lacl }{ }^{\mathrm{q}} \mathrm{Z} \Delta M 15 \operatorname{Tn} 10\left(\mathrm{Tet}^{\mathrm{r}}\right)\right]\end{array}$ & Stratagene, La Jolla, CA \\
\hline XLOLR & $\begin{array}{l}\mathrm{D}(\text { mcrA }) 183 \Delta(\text { mcrCB-hsdSMR-mrr }) 173 \text { endA1 thi-1 recA1gyrA96 relA1 } \Delta \text { lac }\left[\mathrm{F}^{\prime}\right. \\
\left.\quad \text { proAB } 1 \text { lacI }^{\mathrm{q}} \mathrm{Z} \Delta M 15 \mathrm{Tn} 10\left(\mathrm{Tet}^{\mathrm{r}}\right)\right] \mathrm{Su}^{-} \lambda^{\mathrm{r}}\end{array}$ & Stratagene \\
\hline \multicolumn{3}{|c|}{$P=0 x^{2}$} \\
\hline pLAFR3 & Broad-host-range cosmid vector, Tet ${ }^{r}$ & Staskawicz et al. 1987 \\
\hline pUC19 & Cloning and expression vector, $\mathrm{Amp}^{\mathrm{r}}$ & Yanisch-Perron et al. 1985 \\
\hline $\mathrm{pBK}-\mathrm{CMV}$ & Cloning and expression vector, $\mathrm{Amp}^{\mathrm{r}}$ & Stratagene \\
\hline pBSIISK+ & Cloning and expression vector, $\mathrm{Amp}^{\mathrm{r}}$ & Stratagene \\
\hline pRK2013 & Helper plasmid for triparental mating, $\operatorname{Kan}^{\mathrm{r}}$ & Figurski and Helinski 1979 \\
\hline cosSL1 pLAFR3 & Cntaining 24-b genomic DNA from $S$. meliloti surrounding sqd genes & This study \\
\hline pMP3510 & Boad-host-ange plasmid, IncP, Tet $^{r}$ & Spaink et al. 1995 \\
\hline pTB3131 & $n p t$ of $\operatorname{Tn} 5$ in pUC19 & M. Schobert \\
\hline pBW1 & $\begin{array}{l}0.7 \text { kb polymerase chain reaction fragment of sinorhizobial } s q d B \text {, blunt-end } \\
\text { cloned in pBSIISK }{ }^{+}\end{array}$ & This study \\
\hline pBW9 & $\begin{array}{l}\text { 3.5-kb fragment carrying the sinorhizobial } s q d B, s q d D \text { genes and a part of } s q d C \text { in } \\
\text { pBK-CMV }\end{array}$ & This study \\
\hline pBW20 & 3.3-kb Age I/XbaI fragment ofpBW9 in pUC19 & This study \\
\hline pBW22 & pBW20 with $n p t$ of pTB3131inserted in NcoI of $s q d B$ & This study \\
\hline pBW24 & 4.2-kb KpnI/XbaI fragment of pBW22 in pMP3510 & This study \\
\hline pBW41 & 10-kb fragment of cosSL1 inserted into Pst of pUC19 & This study \\
\hline
\end{tabular}


isolated from S. meliloti 1021 wild type, partially digested with Sau3A, and 2- to 4-kbp fragments were ligated into prepared phage arms according to the manufacturer's instructions. The phage library was screened by DNA/DNA-hybridization with Hybond $\mathrm{N}^{+}$filters (Amersham, Piscataway, $\mathrm{NJ}$ ) and a $\left[{ }^{32} \mathrm{P}\right]$ phosphate-labeled probe. Hybridization was performed at $66^{\circ} \mathrm{C}$ overnight in hybridization buffer $(0.255 \mathrm{M}$ $\mathrm{Na}_{\mathrm{x}} \mathrm{PO}_{4}, 6.65 \%$ sodium dodecyl sulfate (SDS), $1 \mathrm{mM}$ EDTA, $10 \mathrm{~g}$ of bovine serum albumin per liter). The filters were washed twice at $66^{\circ} \mathrm{C}$ for $20 \mathrm{~min}$ in $2 \times \mathrm{SSC}(1 \times \mathrm{SSC}$ is 0.15 $\mathrm{M} \mathrm{NaCl}$ plus $0.015 \mathrm{M}$ sodium citrate), $0.5 \%$ (wt/vol) SDS prior to exposure. In vivo excision of a positive clone according to the manufacturer's instructions gave rise to plasmid pBW9 with an insert size of $3.5 \mathrm{~kb}$. The cosmid library was screened with a digoxigenin (DIG)-labeled probe at $68^{\circ} \mathrm{C}$ overnight according to the manufacturer's instructions (Boehringer, Mannheim, Germany). The same conditions as for the cosmid library were used for the Southern blot. Routine nucleic acid manipulations were done as described (Sambrook et al. 1989).

\section{Insertional inactivation of $s q d B$.}

For inactivation of the $s q d B$ open reading frame, the plasmid pBW9 (Fig. 1B) was digested with AgeI and XbaI. The ends of the resulting 3.3-kb DNA fragment were filled in and ligated into pUC19 digested with SmaI, giving rise to pBW20. The $s q d B$ open reading frame was cut with $N c o$ I and filled in, and the neomycin phosphotransferase cassette of pTB3131 inserted in opposite orientation relative to $s q d B$, giving rise to pBW22. The 4.2-kb insert was released with $K p n \mathrm{I} / \mathrm{Xba \textrm {I }}$ and inserted into the broad-host-range vector pMP3510 to obtain pBW24. Plasmid pBW24 was transferred into E. coli. The resulting strain was used for triparental mating. For this purpose, the $S$. meliloti wild type, helper strain, and $E$. coli strain carrying the plasmid pBW24 were grown to an $\mathrm{OD}_{620}$ of 0.3 and mixed in a ratio of 5:2:1 ( $\mathrm{vol} / \mathrm{vol})$. Following an overnight incubation at $29^{\circ} \mathrm{C}$ on TY agar-solidified medium, the exconjugants were selected in the presence of streptomycin, tetracycline, and piperacillin at concentrations indicated above. In a second conjugation step, the IncP-incompatible plasmid pGM2 was transferred into the exconjugants to select for loss of pBW24 and concomitant integration of the kanamycin cassette into the genome as previously described (Østeras et al. 1998). The selection of the knock-out mutants was performed on TY medium with piperacillin, gentamicin, and neomycin added as indicated above. To screen for double recombinant mutants, the positive clones were also streaked onto TY medium containing tetracycline. Putative candidates were further analyzed by Southern hybridization to ensure complete segregation of wild-type genome copies. The finally isolated, sqdB-deficient $S$. meliloti strain was designated SLD11.

\section{In vivo labeling with $\left[{ }^{14} \mathrm{C}\right]$ acetate or $\left[{ }^{35} \mathrm{~S}\right]$ sulfate and lipid analysis.}

The lipid compositions of S. meliloti 1021 wild type and mutant strains were determined following labeling with [1${ }^{14} \mathrm{C}$ ]acetate. Conditions were chosen to ensure homogeneous labeling of the different pools. Cultures $(1 \mathrm{ml})$ of wild type and mutant were grown in minimal medium with two different concentrations of phosphate $(1.3$ and $0.02 \mathrm{mM})$ following in- oculation with precultures containing the same media. After addition of $0.4 \mu \mathrm{Ci}\left[1-{ }^{14} \mathrm{C}\right]$ acetate $(60 \mathrm{nCi} / \mathrm{nmol})$, the cultures were incubated for $24 \mathrm{~h}$. To specifically visualize the sulfolipid, labeling experiments with $\left[{ }^{35} \mathrm{~S}\right]$ sulfate were performed in minimal medium $(1 \mathrm{ml})$ with a reduced sulfate concentration $(0.1 \mathrm{mM})$ containing $1 \mu \mathrm{Ci}$ carrier-free $\left[{ }^{35} \mathrm{~S}\right]$ sulfate. The cells were harvested by centrifugation, washed with $500 \mathrm{ml}$ of water and resuspended in $100 \mathrm{ml}$ of water. The lipids were extracted according to Bligh and Dyer (1959). Prior to quantification, the radioactive lipid extracts were analyzed on highperformance TLC silica gel 60 F254 plates (Merck, Darmstadt, Germany). In the case of one-dimensional TLC the solvent consisted of chloroform/methanol/water (14:6:1, vol/vol); in the case of two-dimensional TLC analysis the same solvent was used in the first dimension and chloroform/methanol/glacial acetic acid (13:5:2, vol/vol) in the second dimension. After exposure to Biomax MR-1 film (Kodak, Rochester, NY), the lipids were visualized by iodine staining. Quantification of ${ }^{14} \mathrm{C}$-labeled lipids was done by transferring lipid containing silica to vials and subsequent scintillation counter analysis.

\section{Nodulation test on alfalfa.}

Seeds of Medicago sativa (alfalfa) were surface sterilized and germinated as previously described (van Brussel et al. 1986). The seedlings were transferred to Jensen-Agar (van Brussel et al. 1982) and inoculated with mutant and wild-type strain cultures grown in minimal medium $\left(\mathrm{OD}_{620}=0.01\right)$. Controls were inoculated with sterilized water. The plants were incubated under natural day light (approximately $10 \mathrm{~h}$ per day) at room temperature for 10 or 12 weeks. During the first weeks, the seedlings were examined for root nodules every 3 to 4 days. Bacteria were reisolated from the nodules according to Somasegaran and Hoben (1994) and tested for the presence of sulfolipid as described above.

\section{Computer analysis.}

Multiple sequence alignments were performed (PileUp) and relationships were calculated (Distances) with GCG software version 10 (Genetics Computer Group, Madison, WI). A dendrogram based on the SQDB or SQD1 amino acid sequences from different organisms was constructed with GrowTree of the GCG package according to Sneath and Sokal (1973).

\section{Nucleotide sequence.}

A 3,989-bp long nucleotide sequence containing the $s q d B$, $s q d C$, and $s q d D$ genes of $S$. meliloti has been deposited at GenBank (accession no. AF194444).

\section{ACKNOWLEDGMENTS}

The contribution by C. B. was financially supported in parts by grants from the U.S. Department of Energy (98ER20305) and the U.S. National Science Foundation (MCB9807943). We thank R. Hollingsworth for his critique of the manuscript.

\section{LITERATURE CITED}

Abraham, W. R., Meyer, H., Lindholst, S., Vancanneyt, M., and Smit, J. 1997. Phospho- and sulfolipids as biomarkers of Caulobacter sensu lato, Brevundimonas and Hyphomonas. System. Appl. Microbiol. 20: 522-539.

Benning, C. 1998. Biosynthesis and function of the sulfolipid sulfoqui- 
novosyl diacylglycerol. Annu. Rev. Plant Physiol. Plant Mol. Biol. 49:53-75.

Benning, C., Beatty, J. T., Prince, R. C., and Somerville, C. R. 1993. The sulfolipid sulfoquinovosyldiacylglycerol is not required for photosynthetic electron transport in Rhodobacter sphaeroides but enhances growth under phosphate limitation. Proc. Natl. Acad. Sci. USA 90: $1561-1565$.

Benning, C., and Somerville, C. R. 1992a. Isolation and genetic complementation of a sulfolipid-deficient mutant of Rhodobacter sphaeroides. J. Bacteriol. 174:2352-2360.

Benning, C., and Somerville, C. R. 1992b. Identification of an operon involved in sulfolipid biosynthesis in Rhodobacter sphaeroides. J. Bacteriol. 174:6479-6487.

Benson, A. A. 1963. The plant sulfolipid. Adv. Lipid Res. 1:387-394.

Benson, A. A., Daniel, H., and Wiser, R. 1959. A sulfolipid in plants. Proc. Natl. Acad. Sci. USA 45:1582-1587.

Beringer, J. E. 1974. R factor transfer in Rhizobium leguminosarum. J. Gen. Microbiol. 84:188-198.

Bligh, E. G., and Dyer, W. J. 1959. A rapid method of total lipid extraction and purification. Can. J. Biochem. Physiol. 37:911-917.

Breedveld, M. W., and Miller, K. J. 1994. Cyclic $\beta$-glucans of members of the Rhizobiaceae. Mol. Microbiol. 58:145-161.

Cedergreen, R. A., and Hollingsworth, R. I. 1994. Occurrence of sulfoquinovosyl diacylglycerol in some members of the family Rhizobiaceae. J. Lipid Res. 35:1452-1461.

de Rudder, K. E. E., Thomas-Oates, J. E., and Geiger, O. 1997. Rhizobium meliloti mutants deficient in phospholipid $N$-methyltransferase still contain phosphatidylcholine. J. Bacteriol. 179:6921-6928.

Dénarié, J., Debellé, F., and Promé, J.-C. 1996. Rhizobium lipo-chitooligosaccharide nodulation factors: Signaling molecules mediating recognition and morphogenesis. Annu. Rev. Biochem. 65:503-535.

Essigmann, B., Güler, S., Narang, R. A., Linke, D., and Benning, C. 1998. Phosphate availability affects the thylakoid lipid composition and the expression of $S Q D 1$, a gene required for sulfolipid biosynthesis in Arabidopsis thaliana. Proc. Natl. Acad. Sci. USA 95:1950-1955.

Essigmann, B., Hespenheide, B. M., Kuhn, L. A., and Benning, C. 1999 Prediction of the active-site structure and $\mathrm{NAD}^{+}$binding in SQD1, a protein essential for sulfolipid biosynthesis in Arabidopsis. Arch. Biochem. Biophys. 369:30-41.

Figurski, D., and Helinski, D. R. 1979. Replication of an origincontaining derivative of plasmid RK2 dependent on a plasmid function in trans. Proc. Natl. Acad. Sci. USA 76:1648-1652.

Geiger, O., Röhrs, V., Weissenmayer, B., Finan, T. M., and ThomasOates, J. E. 1999. The regulator gene phoB mediates phosphate stresscontrolled synthesis of the membrane lipid diacylglyceryl- $N, N, N$ trimethylhomoserine in Rhizobium (Sinorhizobium) meliloti. Mol. Microbiol. 32:63-73.

Goldfine, H. 1987. Lipids of procaryotes - structure and distribution. Curr. Top. Membr. Transp. 17:1-43.

Güler, S., Seeliger, A., Härtel, H., Renger, G., and Benning, C. 1996. A null mutant of Synechococcus sp. PCC7942 deficient in the sulfolipid sulfoquinovosyl diacylglycerol. J. Biol. Chem. 271:7501-7507.

Haines, T. H. 1973. Sulfolipids and halosulfolipids. Pages 197-232 in: Lipids and Biomembranes of Eucaryotic Organisms. J. A. Erwin, ed. Academic Press, New York.

Harwood, J. L. 1980. Sulfolipids. Pages 301-320 in: The Biosynthesis of Plants. P. K. Stumpf, ed. Academic Press, New York.

Heinz, E. 1993. Recent investigations on the biosynthesis of the plant sulfolipid. Pages 163-178 in: Sulfur Nutrition and Assimilation in Higher Plants. L. J. De Kok, ed. SPB Academic Publishing, The Hague, The Netherlands.

Langworthy, T. A., Mayberry, W. R., and Smith, P. F. 1976. A sulfonolipid and novel glucosamidyl glycolipids from the extreme thermoacidophile Bacillus acidocaldarius. Biochim. Biophys. Acta 431: 550-569.

Leigh, J. A., and Walker, G. C. 1994. Exopolysaccharides of Rhizobium:
Synthesis, regulation and symbiotic function. Trends Genet. 10:63-67.

Meade, H. M., Long, S. R., Ruvkun, G. B., Brown, S. E., and Ausubel, F. M. 1982. Physical and genetic characterization of symbiotic and auxotrophic mutants of Rhizobium meliloti induced by transposon Tn5 mutagenesis. J. Bacteriol. 149:114-122.

Mulichak, A. M., Theisen, M. J., Essigmann, B., Benning, C., and Garavito, M. 1999. Crystal structure of SQD1, an enzyme involved in the biosynthesis of the plant sulfolipid headgroup donor UDPsulfoquinovose. Proc. Natl. Acad. Sci. USA 96:13097-13102.

Noel, K. D. 1992. Rhizobial polysaccharides required in symbiosis with legumes. Pages 341-357 in: Molecular Signals in Plant-Microbe Communications. D. P. S. Verma, ed. CRC Press, Boca Raton, FL.

Østeras, M., Boncompagni, E., Vincent, N., Poggi, M. C., and Le Rudulier, D. 1998. Presence of a gene encoding choline sulfatase in Sinorhizobium meliloti bet operon: Choline-O-sulfate is metabolized into glycine betaine. Proc. Natl. Acad. Sci. USA 95:11394-11399.

Reuhs, B. L., Williams, M. N. V., Kim, J. S., Carlson, R. W., and Cote, F. 1995. Suppression of the $\mathrm{Fix}^{-}$phenotype of Rhizobium meliloti exoB mutants by lps $Z$ is correlated to a modified expression of the $\mathrm{K}$ polysaccharide. J. Bacteriol. 177:4289-4296.

Rossak, M., Tietje, C., Heinz, E., and Benning, C. 1995. Accumulation of UDP-sulfoquinovose in a sulfolipid-deficient mutant of Rhodobacter sphaeroides. J. Biol. Chem. 270:25792-25797.

Rossak, M., Schäfer, A., Xu, N., Gage, D. A., and Benning, C. 1997. Accumulation of sulfoquinovosyl-1- $O$-dihydroxyacetone in a sulfolipid-deficient mutant of Rhodobacter sphaeroides inactivated in sqdC. Arch. Biochem. Biophys. 340:219-230.

Sambrook, J., Fritsch, E. F., and Maniatis, T. A. 1989. Molecular Cloning: A Laboratory Manual. 2nd ed. Cold Spring Harbor Laboratory, Cold Spring Harbor, NY.

Schultze, M., Kondorosi, E., Ratet, P., Buire, M., and Kondorosi, A. 1994. Cell and molecular biology of Rhizobium-plant interactions. Int. Rev. Cytol. 156:1-75.

Sherwood, M. T. 1970. Improved synthetic medium for the growth of Rhizobium. J. Appl. Bacteriol. 33:708-713.

Sneath, P. H. A., and Sokal, R. R. 1973. Numerical Taxonomy. Freeman, San Francisco.

So, R. B., Ladha, J. K., and Young, J. P. 1994. Photosynthetic symbionts of Aeschynomene spp. form a cluster with bradyrhizobia on the basis of fatty acid and rRNA analyses. J. Syst. Bacteriol. 44:392-403.

Somasegaran, P., and Hoben, H. J. 1994. Handbook for Rhizobia. Springer Laboratory, New York.

Spaink, H. P., Wijfjes, A. H., and Lugtenberg, B. J. J. 1995. Rhizobium NodI and NodJ proteins play a role in the efficiency of secretion of lipochitin oligosaccharides. J. Bacteriol. 177:6276-6281.

Staskawicz, B., Dahlbeck, D., Keen, N., and Napoli, C. 1987. Molecular characterization of cloned avirulence genes from race 0 and race 1 of Pseudomonas syringae pv. glycinea. J. Bacteriol. 169:5789-5794.

van Brussel, A. A. N., Tak, T., Wetselaar, A., Pees, E., and Wijffelman, C. A. 1982. Small Leguminosae as test plants for nodulation by Rhizobium leguminosarum and other Rhizobia and Agrobacterium harbouring a leguminosarum Sym plasmid. Plant Sci. Lett. 27:317-325.

van Brussel, A. A. N., Zaat, S. A. J., Canter Cremers, H. J. C., Wijffelman, C. A., Pees, E., Tak, T., and Lugtenberg, B. J. J. 1986. Role of plant root exudate and Sym plasmid-localized nodulation genes in the synthesis by Rhizobium leguminosarum of Tsr factor, which causes thick and short roots on common vetch. J. Bacteriol. 165:517-522.

Woese, C. R. 1987. Bacterial evolution. Microbiol. Rev. 51:221-271.

Woodcock, D. M., Crowther, P. J., Doherty, J., Jefferson, S., DeCruz, E., Noyer-Weidner, M., Smith, S. S., Michael, M. Z., and Graham, M. W. 1989. Quantitative evaluation of Escherichia coli host strains for tolerance to cytosine methylation in plasmid and phage recombinants. Nucleic Acids. Res. 17:3469-3478.

Yanisch-Perron, C., Vieira, J., and Messing, J. 1985. Improved M13 phage cloning vectors and host strains: nucleotide sequences of the M13mp18 and pUC19 vectors. Gene 33:103-119. 